Arianna Giunti@ · Felix Otto

\title{
Erratum to: On the existence of the Green function for elliptic systems in divergence form
}

Published online: 19 July 2021

\section{Erratum to: manuscripta math. https://doi.org/10.1007/s00229-021-01271-0}

The article On the existence of the Green function for elliptic systems in divergence form, written by Arianna Giunti, Felix Otto, was originally published Online First without Open Access. After publication the author decided to opt for Open Choice and to make the article an Open Access publication. Therefore, the copyright of the article has been changed to (CThe Author(s) 2021 and the article is forthwith distributed under the terms of the Creative Commons Attribution 4.0 International License, which permits use, sharing, adaptation, distribution and reproduction in any medium or format, as long as you give appropriate credit to the original author(s) and the source, provide a link to the Creative Commons licence, and indicate if changes were made. The images or other third party material in this article are included in the article's Creative Commons licence, unless indicated otherwise in a credit line to the material. If material is not included in the article's Creative Commons licence and your intended use is not permitted by statutory regulation or exceeds the permitted use, you will need to obtain permission directly from the copyright holder. To view a copy of this licence, visit http://creativecommons.org/ licenses/by/4.0.

Open Access This article is licensed under a Creative Commons Attribution 4.0 International License, which permits use, sharing, adaptation, distribution and reproduction in any medium or format, as long as you give appropriate credit to the original author(s) and the source, provide a link to the Creative Commons licence, and indicate if changes were made. The images or other third party material in this article are included in the article's Creative Commons licence, unless indicated otherwise in a credit line to the material. If material is not included in the article's Creative Commons licence and your intended use is not permitted by statutory regulation or exceeds the permitted use, you will need to obtain permission directly from the copyright holder. To view a copy of this licence, visit http://creativecommons.org/ licenses/by/4.0/.

The original article can be found online at https://doi.org/10.1007/s00229-021-01271-0. Arianna Giunti $(\varangle)$ : Institute for Applied Mathematics, Bonn, Germany e-mail: a.giunti@imperial.ac.uk

Felix Otto: Max Planck Institute for Mathematics in the Sciences, Leipzig, Germany 
Publisher's Note Springer Nature remains neutral with regard to jurisdictional claims in published maps and institutional affiliations. 